\title{
Using Flaming as an Alternative Method to Vine Suckering
}

\author{
Luisa Martelloni *(D), Michele Raffaelli, Christian Frasconi, Marco Fontanelli, Andrea Peruzzi \\ and Claudio D'Onofrio
}

Department of Agriculture, Food and Environment, University of Pisa, Via del Borghetto 80, 56124, Pisa, Italy; michele.raffaelli@unipi.it (M.R.); christian.frasconi@unipi.it (C.F.); marco.fontanelli@unipi.it (M.F.);

andrea.peruzzi@unipi.it (A.P.); claudio.donofrio@unipi.it (C.D.)

* Correspondence: 1martelloni@agr.unipi.it; Tel.: +39-050-2218-966

Received: 19 February 2019; Accepted: 19 March 2019; Published: 21 March 2019

check for updates

\begin{abstract}
Suckering is the process of removing the suckers that grapevine trunks put out in the spring. Suckering by hand is costly and time consuming and requires constant bending down, getting up and making repetitive motions. The mechanical removal of suckers with rotating scourges can damage the vine plants. Chemical suckering is a limiting factor for wine grape growers interested in sustainable and/or organic agriculture. The aim of this research was to test flaming as an alternative method to vine suckering. A three-year experiment was conducted on a 10-year-old Sangiovese vine (775 Paulsen rootstock). The treatments consisted of flame suckering at different phenological stages, hand-suckering and a no-suckered control. Data on the number of suckers, grape yield components, and grape composition were collected and analysed. The results showed that flaming significantly reduced the initial number of suckers. This effect on the suckers was highest when the main productive shoots of the vines were at the 18-19 BBCH growth stage. Flame-suckering did not affect grape yield components and grape composition. Future studies could investigate the simultaneous use of flaming for both suckering and weed control.
\end{abstract}

Keywords: grapevine; no-chemical; organic agriculture; sucker removal; Vitis vinifera (L.); thermal

\section{Introduction}

Suckers are nonbearing shoots that grow in the spring from latent buds on grapevine (Vitis vinifera L.) trunks [1]. Sucker growth can lead to excess vegetation, increase the possibility of attack from pathogens and alter the fruit/shoot ratio [2]. Moreover, suckers can cause problems during vineyard management operations, such as soil tillage, weed removal, mechanical harvest, and pest and disease control [3]. To overcome these problems suckers are removed during grapevine cultivation and this process is known as suckering. The right time for suckering is when they are not yet lignified. Waiting longer causes the suckers to become lignified, harden, which are then more difficult to remove. Suckering in spring also prevents the development of resprouting basal buds [4].

Traditionally, suckering was done by hand, however this is costly and time consuming because it requires constant bending down, getting up and making repetitive motions [5]. Hand suckering requires an operating time ranging from a minimum of $20 \mathrm{~h} \mathrm{ha}^{-1}$ to a maximum of $60-70 \mathrm{~h} \mathrm{ha}-1$, depending on the operating conditions [6]. The mechanical removal of suckers by scourges is widely employed, however this is generally stressful on young plants, which can be damaged by rotating scourges [2]. Chemical suckering with traditional herbicides or synthetic growth regulators is also widely used [2,7], however the use of synthetic chemicals is forbidden for organic wine grape growers.

Flaming could be a viable nonchemical alternative to remove the not yet lignified spring suckers. The high temperature of the flame denaturises the plant proteins of green tissues, without burning, and 
thus desiccates them [8]. Flame-suckering could be useful for organic viticulture, which has received increased interest by grapevine growers in the recent decades.

Flaming is currently used to control weeds in heat-tolerant herbaceous and horticultural crops [9-12], however, to the best of our knowledge, there has been no research using flaming to remove suckers from grapevines. This research tests the effects of flaming to remove the suckers. Grape yield components and grape composition were also recorded.

\section{Materials and Methods}

\subsection{Experimental Set Up}

A three-year experiment (2016, 2017 and 2018) was conducted on a 10-year-old Sangiovese vine (clone BF-30) grafted on 775 Paulsen rootstock. The farm (Tenuta Ceppaiano, Castellani Spa) was located in Tuscany, Italy $\left(43^{\circ} 35^{\prime} 51.6^{\prime \prime} \mathrm{N} 10^{\circ} 32^{\prime} 13.8^{\prime \prime} \mathrm{E}\right)$. The vineyard training system was spurred cordon. The cordons were $80 \mathrm{~cm}$ height. The distance between each vine on the row was $80 \mathrm{~cm}$, and between the rows was $2.10 \mathrm{~m}$, for a density of 5952 plants per ha. The soil was loam $(40 \%$ sand, $34 \%$ silt, $26 \%$ clay, $1 \%$ organic matter, $\mathrm{pH}=7$ ). Figure 1 reports the monthly-cumulated rainfall and monthly average temperatures recorded during the three-year experiment. Fertilization consisted of the application of an organic-mineral fertilizer in January 2016 and 2017 (10N-5P-14K and 8N-16P-24K, respectively), and calcium nitrate $(15.5 \mathrm{~N}-0 \mathrm{P}-0 \mathrm{~K})$ in January 2018 . Sixteen, eight and eleven chemical treatments, against Plasmopara viticola (Berk. \& M.A. Curtis) and Uncinula necator (Schwein.) Burrill, were applied from April to August in 2016, 2017 and 2018, respectively. One chemical treatment against Lobesia botrana (Schiff. et Den.) was applied in June in 2016 and 2018. The vineyard was not irrigated.

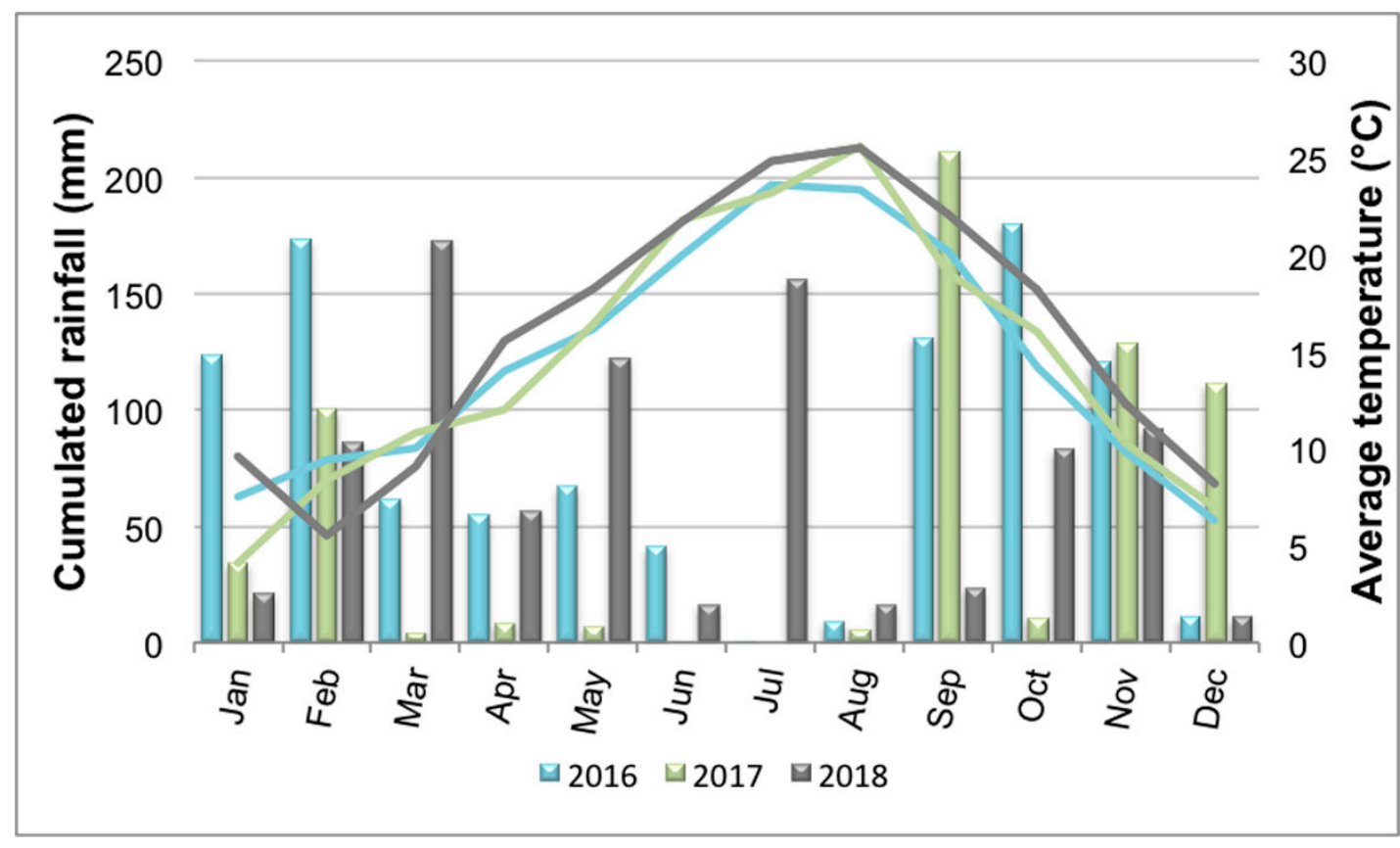

Figure 1. Monthly cumulated rainfall and monthly average temperatures (January 2016-December 2018) recorded by the meteorological station in Siberia, Crespina-Lorenzana (Pisa, Italy) $\left(43^{\circ} 35^{\prime} 31.2^{\prime \prime} \mathrm{N}\right.$ $10^{\circ} 32^{\prime} 38.4^{\prime \prime}$ E) [13].

The flaming machine used for suckering was the PFV-600 model (Officine Mingozzi, Ferrara, Italy) [14] (Figure 2). A mobile horizontal frame supports the burners, which are placed in two rows in a staggered position. The inclination of the burner rows can be adjusted based on the height of the suckers. The burners were cylindrical with air-intake and operated in gaseous phase (Figure 2) [15]. The flaming machine was coupled with a SAME Frutteto 100 (Same, Treviglio, Bergamo, Italy) tractor. 


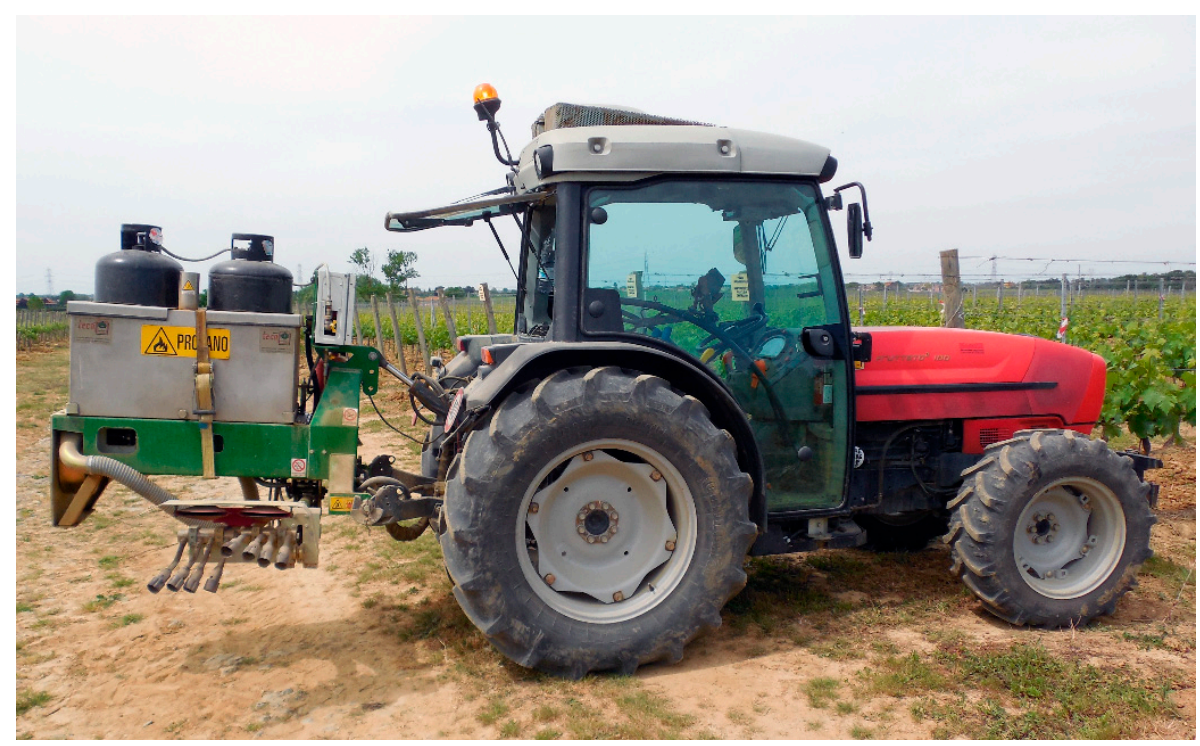

Figure 2. The flaming machine PFV-600 (Officine Mingozzi, Ferrara, Italy) coupled with a SAME Frutteto 100 (SAME, Treviglio, Italy) tractor.

The flaming machine was supplied with liquefied petroleum gas (LPG). The LPG consumption at the pressure of $0.2 \mathrm{MPa}$ was $17.64 \mathrm{~kg} \mathrm{~h}^{-1}$. The working width was $1.05 \mathrm{~m}$ (half of the $2.10 \mathrm{~m}$ inter-row space) and the forward speed was $3 \mathrm{~km} \mathrm{~h}^{-1}$. The machine distributed $55.90 \mathrm{~kg} \mathrm{ha}^{-1}$ of LPG. The LPG dose actually applied to the suckers (within the intra-row space of $0.30 \mathrm{~m}$ ) was $195.65 \mathrm{~kg}$ $\mathrm{ha}^{-1}$. This LPG dose was chosen because it was deemed effective to devitalize suckers on the basis of previous experiments where flaming was used to devitalize weeds and cover crops [10,11,16-19].

Each year, the first flaming was applied in the spring when the vine plants showed the most developed suckers at the 12-13 $\mathrm{BBCH}$ growth stage (two-three unfolded leaves) and the main productive shoots at the 15-16 BBCH growth stage (five-six unfolded leaves) [20] (21 April in 2016 and 2017, 2 May in 2018) (Figures 3 and 4) (Supplementary Materials). The second flaming was applied when the nonflamed plants showed the most developed suckers at the 15-16 BBCH growth stage and the main shoots at the 18-19 BBCH growth stage (eight-nine unfolded leaves) (5 May in 2016 and 2017, 16 May in 2018). Hand suckering was conducted on the same date as the first flaming. The control was not suckered in the spring, but lignified suckers were manually removed during the winter pruning. The suckers that remained on the plants after the flaming and hand suckering, or that had resprouted, were also removed during the winter pruning. 


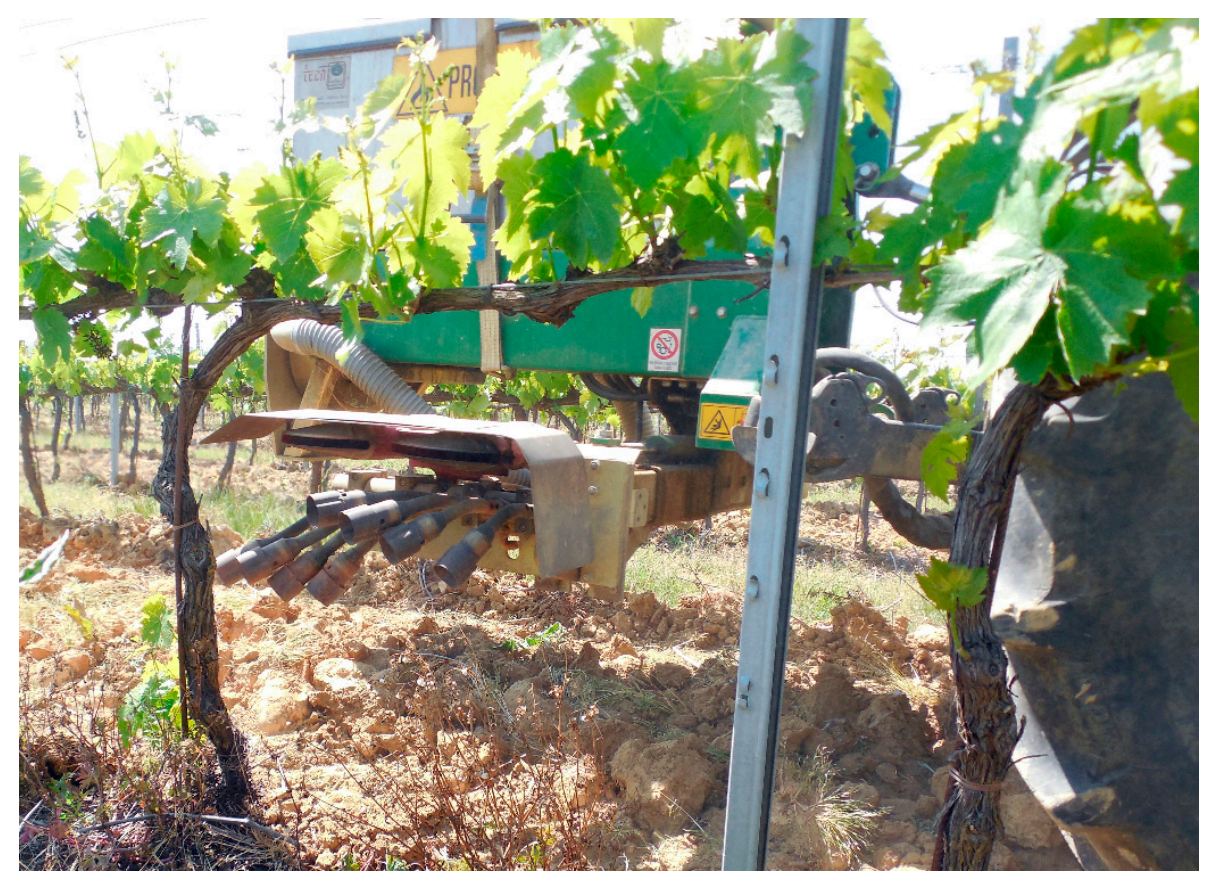

Figure 3. Flame suckering applied on 21 April 2017 at the 13 BBCH sucker growth stage.

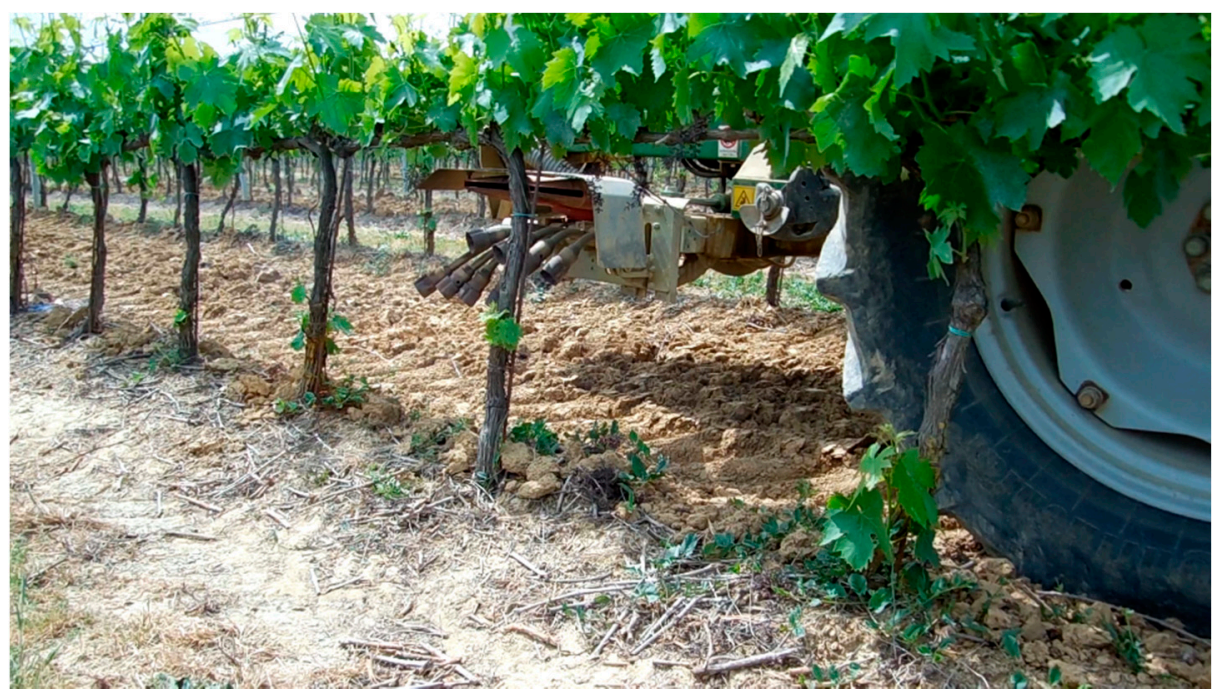

Figure 4. Flame suckering applied on 21 April 2016 at the 12-13 BBCH sucker growth stage.

The experimental design was a randomized complete block design. Five adjacent vineyard rows were selected, and each row was divided into five 16-m-long blocks (one for each treatment). Treatments were: (1) flaming applied once only when the most developed suckers were at the 12-13 BBCH growth stage (treatment "FlamingA"), (2) flaming applied once only when the most developed suckers were at the 15-16 BBCH growth stage (treatment "FlamingB"), (3) flaming applied twice, the first time when the most developed suckers were at the 12-13 $\mathrm{BBCH}$ growth stage, and the second time at the same date as FlamingB (treatment "FlamingC"), (4) hand suckering when the most developed suckers were at the 12-13 BBCH growth stage (treatment "Hand"), and (5) nonsuckered plants (treatment "Control") (Table 1). 
Table 1. Date of suckering treatments, and the growth stage of the most developed suckers at the time of suckering.

\begin{tabular}{|c|c|c|c|}
\hline Treatment & Year & Date of Application & Suckers Growth Stage \\
\hline FlamingA & 2016 & 21 April & \multirow{4}{*}{$\begin{array}{c}12-13 \text { BBCH } \\
15-16 \text { BBCH } \\
12-13 \text { BBCH on } 21 \text { April, } \\
15-16 \text { BBCH on } 5 \text { May } \\
12-13 \text { BBCH }\end{array}$} \\
\hline FlamingB & 2016 & 5 May & \\
\hline FlamingC & 2016 & 21 April and 5 May & \\
\hline Hand & 2016 & 21 April & \\
\hline FlamingA & 2017 & 21 April & \multirow{4}{*}{$\begin{array}{c}12-13 \text { BBCH } \\
15-16 \text { BBCH } \\
12-13 \text { BBCH on } 21 \text { April, } \\
15-16 \text { BBCH on } 5 \text { May } \\
12-13 \text { BBCH }\end{array}$} \\
\hline FlamingB & 2017 & 5 May & \\
\hline FlamingC & 2017 & 21 April and 5 May & \\
\hline Hand & 2017 & 21 April & \\
\hline FlamingA & 2018 & 2 May & \multirow{4}{*}{$\begin{array}{c}12-13 \text { BBCH } \\
15-16 \text { BBCH } \\
12-13 \text { BBCH on } 2 \text { April, } \\
15-16 \text { BBCH on } 16 \text { May } \\
12-13 \text { BBCH }\end{array}$} \\
\hline FlamingB & 2018 & 16 May & \\
\hline FlamingC & 2018 & 2 May and 16 May & \\
\hline Hand & 2018 & 2 May & \\
\hline
\end{tabular}

\subsection{Data Collection}

Each year, data were always collected in relation to the same five vine plants at the centre of each block for a total of 25 replicates for each treatment. The persistence of suckers after treatments was evaluated by counting the number of suckers at four different times: (1) immediately before the first flaming, (2) two weeks after FlamingA, (3) three weeks after FlamingA, and one week after FlamingB, and (4) seven weeks after FlamingA, and five weeks after FlamingB.

In September, at the harvest, all the clusters of each replicate were counted and weighed together in order to evaluate the yield. The average cluster weight $\left(\mathrm{g} \mathrm{cluster}^{-1}\right)$ was calculated by dividing the yield by the number of clusters. The average berry weight $\left(\mathrm{g} \mathrm{berry}^{-1}\right)$ was calculated by averaging the weight of 50 berries randomly picked from the clusters of each replicate.

Immediately after harvest, the berries were placed in hermetically sealed plastic bags and stored in a cooler at $4{ }^{\circ} \mathrm{C}$ to preserve their characteristics. The berries were then crushed and the juice filtered through cheesecloth to determine total soluble solids, $\mathrm{pH}$ and tartaric acid following standard methods (European Commission Regulation (EC) No. 2676/90). Total soluble solids (Brix) were determined at $20^{\circ} \mathrm{C}$ using an ATC digital refractometer (Tekcoplus, Hong Kong, China); pH was measured using a Hanna H18519N electronic pH-meter (Hanna Instruments, Padova, Italy); and tartaric acid was determined by acid-base titration using sodium hydroxide $(0.1 \mathrm{~N})$ to an endpoint $\mathrm{pH}$ of 8 , with values expressed as tartaric acid $\left(\mathrm{g} \mathrm{L}^{-1}\right)$.

Flaming machine performance parameters and costs were calculated. The field efficiency (i.e., the ratio of the theoretical field time and the total time spent in the field) was computed by referring to a hypothetical area of $10,000 \mathrm{~m}^{2}$ (30.00 $\mathrm{m}$ wide and $333.33 \mathrm{~m}$ long). The theoretical field time is the time the machine is effectively operating at an optimum forward speed and performing over its full width of action. The total time for conducting the operation was calculated by summing the machine adjustment time (including plugging and unplugging), the theoretical field time, the turning time, and the time to refuel the tractor and/or replace empty LPG tanks. However, the travelling time back and forth the field was not included. The total cost per use was calculated by summing the fixed and variable costs for the flaming machine coupled with a SAME Frutteto 100, following a standard methodology for cost determination [21]. The rate of depreciation was determined considering a purchase price of $€ 46,445$ for the SAME Frutteto 100, and $€ 12,139$ for the flaming machine. The economic lifetime considered was 12 years for the tractor, and 10 years for the flaming machine. The repairing and maintenance factor was $80 \%$ for the tractor, and $75 \%$ for the flaming machine. The labour costs for the tractor driver was $15 € \mathrm{~h}^{-1}$, and the LPG cost was $2.25 € \mathrm{~kg}^{-1}$. 


\subsection{Statistical Analysis}

Data normality was assessed using the Shapiro-Wilk test. Other tests consisted of the Student $\mathrm{t}$-test to verify that the mean error was not significantly different to zero, the Breusch-Pagan test for homoscedasticity and the Durbin-Watson test for autocorrelation.

Data on the number of suckers were modelled in a generalized linear mixed model using the extension package lmerTest (Tests in Linear Mixed Effects Models) [22] of R software [23]. The $\log$ transformation was assessed. The treatments and data collection dates were the fixed factors. The random factors (replicates and data collection dates) were assessed as longitudinal data (repeated measures) to obtain a correlated random effect for intercept and slope. Data were analysed separately each year. The analysis of deviance was run. The package emmeans (Estimated Marginal Means, aka Least-Squares Means) [24] was used to compute the least squares means, standard errors, inverse transformed values, and confidence intervals.

Yield components and grape composition data were modelled in a linear mixed model using the extension package lmerTest [22] of $\mathrm{R}$ software [23]. Treatments and years were the fixed factor, and replicates and years were the random factors. The analysis of variance was run. The package lmerTest [22] was used to compute the least squares means and standard errors.

Pairwise comparisons between estimated least squares means were computed by estimating the $95 \%$ confidence interval of the difference between the least squares means (Equation (1)):

$$
\mathrm{CI}(\text { difference })=\left(x_{1}-x_{2}\right) \pm 1.96 \sqrt{\left(\mathrm{SE}_{x_{1}}\right)^{2}+\left(\mathrm{SE}_{x_{2}}\right)^{2}}
$$

where $\left(x_{1}\right)$ is the mean of the first value, $\left(x_{2}\right)$ is the mean of the second value, (SE $\left.x_{1}\right)$ is the standard error of $\left(x_{1}\right)$, and $\left(\mathrm{SE} x_{2}\right)$ is the standard error of $\left(x_{2}\right)$ [25].

If the resulting $95 \%$ confidence interval (CI) of the difference between values did not cross the zero value, the null hypothesis that the compared values were not different was rejected.

\section{Results}

\subsection{Number of Suckers}

The analysis of deviance showed in all the years that the number of suckers was influenced by the type of treatment, the data collection date, and their interaction $(p<0.001$, respectively). For each year of the experiment, the least squares means and the standard errors of the number of suckers log transformed are reported in Table 2. Inverse transformed values and lower and upper confidence intervals are reported in Table 3. The number of suckers before the first flaming was similar between treatments in all years. In 2016, all the flaming treatments and hand suckering significantly reduced the number of suckers compared to the initial number of suckers. In 2017 and 2018 only FlamingA (suckers flamed only on 21 April 2017 and 2 May 2018) did not significantly reduce the initial number of suckers. In the control plot, the number of suckers was similar to that before the start of the experiment in all the years (Table 2). 
Table 2. Least squares means of the number of suckers per plant log transformed and standard errors (SE) as affected by different types of suckering methods and data collection date in the three-year experiment. These data are useful for computing all pairwise comparisons.

\begin{tabular}{ccccccc}
\hline \multirow{2}{*}{ Date } & \multirow{2}{*}{ Year } & \multicolumn{5}{c}{ Log (No. of Suckers) ( \pm SE) } \\
\cline { 3 - 6 } & & FlamingA & FlamingB & FlamingC & Hand & Control \\
\hline 21 April & 2016 & $1.38(0.11)$ & $1.40(0.11)$ & $1.43(0.13)$ & $1.58(0.16)$ & $1.37(0.12)$ \\
5 May & 2016 & $0.65(0.17)$ & $1.40(0.12)$ & $0.77(0.18)$ & $0.44(0.28)$ & $1.41(0.13)$ \\
12 May & 2016 & $0.67(0.17)$ & $0.41(0.18)$ & $-0.97(0.41)$ & $0.57(0.26)$ & $1.42(0.13)$ \\
9 June & 2016 & $0.68(0.16)$ & $0.59(0.17)$ & $-0.56(0.34)$ & $0.57(0.26)$ & $1.45(0.12)$ \\
21 April & 2017 & $1.04(0.13)$ & $0.98(0.14)$ & $1.11(0.13)$ & $1.38(0.19)$ & $0.98(0.15)$ \\
5 May & 2017 & $0.80(0.15)$ & $1.10(0.14)$ & $0.73(0.15)$ & $-0.60(0.46)$ & $1.00(0.15)$ \\
12 May & 2017 & $0.98(0.14)$ & $0.50(0.17)$ & $-0.01(0.21)$ & $-0.42(0.42)$ & $1.04(0.14)$ \\
9 June & 2017 & $0.98(0.14)$ & $0.58(0.17)$ & $0.11(0.20)$ & $-0.01(0.35)$ & $1.10(0.14)$ \\
2 May & 2018 & $0.88(0.19)$ & $1.07(0.17)$ & $0.88(0.19)$ & $1.01(0.18)$ & $0.95(0.18)$ \\
16 May & 2018 & $0.28(0.25)$ & $1.12(0.17)$ & $0.08(0.28)$ & $-0.41(0.36)$ & $1.01(0.18)$ \\
23 May & 2018 & $0.40(0.24)$ & $0.22(0.26)$ & $-0.41(0.36)$ & $-0.19(0.32)$ & $1.10(0.18)$ \\
20 June & 2018 & $0.51(0.23)$ & $0.40(0.24)$ & $-0.09(0.31)$ & $-0.01(0.29)$ & $1.18(0.17)$ \\
\hline
\end{tabular}

Flaming A = plants flamed only on 21 April in 2016 and 2017, 2 May in 2018. The most developed suckers were at the 12-13 BBCH growth stage. FlamingB = plants flamed only on 5 May in 2016 and 2017; 16 May in 2018. The most developed suckers were at the 15-16 BBCH growth stage. FlamingC = plants flamed on 21 April and 5 May in 2016 and 2017; 2 May and 16 May 2018. Hand = plants hand suckered on 21 April 2016 and 2017; 2 May in 2018. Control $=$ no suckered plants.

Table 3. Inverse transformed values (from the log scale) and lower and upper confidence intervals (LCI, UCI) of the least squares means of the number of suckers per plant as affected by different type of suckering methods and data collection date in the three-year experiment.

\begin{tabular}{ccccccc}
\hline \multirow{2}{*}{ Date } & \multirow{2}{*}{ Year } & \multicolumn{5}{c}{ No. of Suckers (LCI, UCI) } \\
\cline { 3 - 7 } & & FlamingA & FlamingB & FlamingC & Hand & Control \\
\hline 21 April & 2016 & $3.97(3.17,4.98)$ & $4.04(3.25,5.03)$ & $4.17(3.26,5.34)$ & $4.88(3.59,6.63)$ & $3.93(3.08,5.01)$ \\
5 May & 2016 & $1.92(1.39,2.66)$ & $4.07(3.25,5.11)$ & $2.16(1.52,3.05)$ & $1.55(0.90,2.65)$ & $4.10(3.20,5.25)$ \\
12 May & 2016 & $1.96(1.42,2.71)$ & $1.51(1.06,2.16)$ & $0.38(0.17,0.85)$ & $1.76(1.06,2.94)$ & $4.28(3.37,5.45)$ \\
9 June & 2016 & $1.97(1.43,2.72)$ & $1.80(1.30,2.50)$ & $0.57(0.30,1.10)$ & $1.77(1.07,2.93)$ & $4.28(3.37,5.46)$ \\
21 April & 2017 & $2.84(2.19,3.67)$ & $2.66(2.03,3.48)$ & $3.04(2.37,3.90)$ & $3.97(2.74,5.74)$ & $2.66(2.01,3.52)$ \\
5 May & 2017 & $2.24(1.67,2.99)$ & $3.00(2.30,3.91)$ & $2.08(1.54,2.81)$ & $0.55(0.22,1.35)$ & $2.72(2.04,3.62)$ \\
12 May & 2017 & $2.66(2.01,3.50)$ & $1.65(1.18,2.32)$ & $0.99(0.65,1.50)$ & $0.66(0.29,1.51)$ & $2.84(2.13,3.78)$ \\
9 June & 2017 & $2.68(2.04,3.51)$ & $1.79(1.29,2.48)$ & $1.12(0.76,1.66)$ & $0.99(0.50,1.96)$ & $3.00(2.27,3.95)$ \\
2 May & 2018 & $2.41(1.66,3.50)$ & $2.91(2.07,4.09)$ & $2.41(1.66,3.50)$ & $2.74(1.93,3.89)$ & $2.59(1.81,3.72)$ \\
16 May & 2018 & $1.33(0.81,2.18)$ & $3.07(2.20,4.29)$ & $1.08(0.62,1.87)$ & $0.66(0.33,1.33)$ & $2.76(1.94,3.92)$ \\
23 May & 2018 & $1.49(0.93,2.39)$ & $1.24(0.74,2.08)$ & $0.66(0.33,1.33)$ & $0.83(0.44,1.55)$ & $3.01(2.13,4.24)$ \\
20 June & 2018 & $1.66(1.06,2.60)$ & $1.49(0.93,2.39)$ & $0.91(0.50,1.66)$ & $0.99(0.56,1.77)$ & $3.26(2.35,4.52)$ \\
\hline
\end{tabular}

Flaming A = plants flamed only on 21 April in 2016 and 2017, 2 May in 2018. The most developed suckers were at the 12-13 BBCH growth stage. FlamingB = plants flamed only on 5 May in 2016 and 2017; 16 May in 2018. The most developed suckers were at the 15-16 BBCH growth stage. FlamingC = plants flamed on 21 April and 5 May in 2016 and 2017; 2 May and 16 May 2018. Hand = plants hand suckered on 21 April 2016 and 2017; 2 May in 2018. Control $=$ no suckered plants.

In 2016, on 5 May, the number of suckers in FlamingA and FlamingC was significantly lower compared to FlamingB (not yet flamed) and the control, and similar to the hand-suckered plants. On 12 May, all treatments had a lower number of suckers compared to the control. The number of suckers was also lower in FlamingC compared to other treatments, whereas, FlamingA, FlamingB and the hand-suckered plants showed a statistically similar number of suckers. On 9 June, the differences in the number of suckers between treatments were the same as the previous data collection date (four weeks before) (Table 2).

In 2017, on 5 May, the number of suckers in the flamed plants was similar to the nonflamed plants. The hand-suckered plants showed a significantly lower number of suckers compared to the other treatments. On 12 May, the number of suckers in FlamingC, FlamingB and hand-suckered treatments was similar and significantly lower compared to FlamingA and the control (Flaming A and 
the control were statistically similar). On 9 June, the number of suckers in FlamingA and FlamingB treatments was similar. FlamingA was also similar to the control, whereas FlamingC, FlamingB and the hand-suckering were similar and showed a lower number of suckers compared to the control (Table 2).

In 2018, on 16 May, the number of suckers on the flamed plants was similar to the hand-suckered plants and significantly lower compared to FlamingB and the control. On 23 May, the number of suckers was higher in the control and similar between all other treatments. Flaming and hand-suckering treatments were similar and showed a lower number of suckers compared to the control also on 20 June (Table 2).

In all years, for each flaming treatment and hand suckering, no significant increase in the number of suckers was observed comparing the data collection date after the treatment (two weeks for Flaming $\mathrm{A}$, FlamingC and hand suckering, and one week for FlamingB) and the last data collection date. This thus suggests that in this time period no resprouting of suckers occurred. In all the years, the resprouting of suckers after treatment occurred only during the two weeks between the start of the experiment and the first data collection (i.e., from 21 April to 5 May in 2016 and 2017, and from 2 May and 16 May in 2018) (Table 2).

\subsection{Yield Components and Grape Composition}

For each model, all the $p$-values of the analysis of variance are reported in Table 4 . The suckering method (treatment) and the treatment:year interaction were not significant, whereas the year was significant for all the dependent variables analysed.

Table 4. Analysis of variance for yield, average cluster weight, average berry weight, total soluble solids, $\mathrm{pH}$ and tartaric acid, and analysis of deviance (type II Wald chi-square test) for the number of clusters.

\begin{tabular}{|c|c|c|c|}
\hline \multirow{2}{*}{ Variable } & \multicolumn{3}{|c|}{$p$-Values } \\
\hline & Treatment & Year & Treatment:Year \\
\hline Yield $\left(\mathrm{kg} \mathrm{plant}^{-1}\right)$ & 0.928 & $<0.001$ & 0.743 \\
\hline No. of clusters (cluster plant ${ }^{-1}$ ) & 0.979 & $<0.001$ & 1.000 \\
\hline Average cluster weight ( $\mathrm{g}$ cluster ${ }^{-1}$ ) & 0.435 & $<0.001$ & 0.324 \\
\hline Average berry weight $\left(\mathrm{g}\right.$ berry $\left.^{-1}\right)$ & 0.464 & $<0.001$ & 0.874 \\
\hline Total soluble solids $\left({ }^{\circ}\right.$ Brix $)$ & 0.674 & $<0.001$ & 0.998 \\
\hline $\mathrm{pH}$ & 0.861 & $<0.001$ & 0.685 \\
\hline Tartaric acid $\left(\mathrm{g} \mathrm{L}^{-1}\right)$ & 0.430 & $<0.001$ & 0.730 \\
\hline
\end{tabular}

Table 5 reports the least squares means and standard errors of the yield, clusters number (log transformed and inverse transformed values with the lower and upper $95 \%$ confidence interval), average cluster weight and average berry weight as affected by type of treatment and the year. Within the same year, the yield, number of clusters, and the average weights of the clusters and berries were similar between treatments, suggesting that flame-suckering did not affect yield components.

In the flame-suckered plots, the yield decreased significantly in 2017 compared to 2016, and in 2018 compared to 2017. In the hand-suckered and control plots, the yield was similar in 2016 compared to 2017, whereas in 2018 was lower compared to 2016 and 2017. The average berry weight in 2016 was similar to 2017, whereas it was higher in 2018 compared to 2016 and 2017 for all the treatments. Except for the hand-suckered plants, where the number of clusters per plant was similar in 2016 and 2017, for the other treatments, the number of clusters increased from 2016 to 2017. The number of clusters decreased significantly from 2017 to 2018 for all the treatments. The average cluster weight was significantly lower in 2017 and 2018 compared to 2016 and was similar in 2017 and 2018 for all the treatments. 
Table 5. Least squares means and standard errors of the yield, clusters number (log transformed) average cluster weight and average berry weight as affected by the type of treatment and the year. Inverse transformed values and lower and upper 95\% confidence intervals (LCI, UCI) of clusters number log transformed are reported.

\begin{tabular}{|c|c|c|c|c|c|c|}
\hline \multirow{2}{*}{ Variable } & \multirow{2}{*}{ Year } & \multicolumn{5}{|c|}{ Treatment } \\
\hline & & FlamingA & FlamingB & FlamingC & Hand & Control \\
\hline $\begin{array}{c}\text { Yield }\left(\mathrm{kg} \mathrm{plant}^{-1}\right) \\
\quad( \pm \mathrm{SE})\end{array}$ & 2016 & $3.46(0.24)$ & $3.57(0.24)$ & $3.36(0.24)$ & $3.42(0.39)$ & $3.12(0.24)$ \\
\hline $\begin{array}{l}\text { Yield }\left(\mathrm{kg} \mathrm{plant}^{-1}\right) \\
\qquad( \pm \mathrm{SE})\end{array}$ & 2017 & $2.52(0.24)$ & $2.46(0.24)$ & $2.73(0.25)$ & $2.93(0.39)$ & $2.88(0.24)$ \\
\hline $\begin{array}{l}\left.\text { Yield (kg plant }{ }^{-1}\right) \\
( \pm \mathrm{SE})\end{array}$ & 2018 & $1.80(0.35)$ & $1.50(0.335)$ & $1.56(0.335)$ & $1.91(0.35)$ & $1.51(0.335)$ \\
\hline $\begin{array}{l}\log [\text { Clusters (no. } \\
\left.\left.\text { plant }^{-1}\right)\right]( \pm \text { SE) }\end{array}$ & 2016 & $2.24(0.07)$ & $2.23(0.07)$ & $2.22(0.07)$ & $2.21(0.11)$ & $2.20(0.07)$ \\
\hline $\begin{array}{l}\text { log[Clusters (no. } \\
\left.\left.\text { plant }^{-1}\right)\right]( \pm \mathrm{SE})\end{array}$ & 2017 & $2.42(0.06)$ & $2.42(0.06)$ & $2.41(0.06)$ & $2.38(0.10)$ & $2.40(0.06)$ \\
\hline $\begin{array}{l}\text { log[Clusters (no. } \\
\left.\left.\text { plant }^{-1}\right)\right]( \pm \text { SE) }\end{array}$ & 2018 & $1.98(0.11)$ & $1.94(0.11)$ & $1.93(0.11)$ & $1.94(0.115)$ & $1.94(0.11)$ \\
\hline $\begin{array}{c}\text { Clusters (no. } \\
\text { plant }^{-1} \text { ) }(\mathrm{LCI}, \mathrm{UCI})\end{array}$ & 2016 & $9.42(8.25,10.77)$ & $9.34(8.17,10.68)$ & $9.21(8.05,10.54)$ & $9.08(7.28,11.32)$ & $9.05(7.90,10.36)$ \\
\hline $\begin{array}{c}\text { Clusters (no. } \\
\text { plant }^{-1} \text { ) }(\mathrm{LCI}, \mathrm{UCI})\end{array}$ & 2017 & $11.30(10.00,12.77)$ & $11.21(9.92,12.68)$ & $11.14(9.82,12.63)$ & $10.85(8.85,13.29)$ & $11.01(9.72,12.46)$ \\
\hline $\begin{array}{c}\text { Clusters (no. } \\
\text { plant }^{-1} \text { ) (LCI, UCI) }\end{array}$ & 2018 & $7.25(5.81,9.04)$ & $6.97(5.61,8.64)$ & $6.88(5.54,8.55)$ & $6.94(5.53,8.70)$ & $6.97(5.61,8.64)$ \\
\hline $\begin{array}{c}\text { Average cluster } \\
\text { weight }\left(\mathrm{g}^{\text {cluster }}{ }^{-1}\right) \\
( \pm \mathrm{SE})\end{array}$ & 2016 & 357.09 (17.37) & $389.24(17.37)$ & $368.13(17.37)$ & 379.66 (28.33) & 344.07 (17.37) \\
\hline $\begin{array}{c}\text { Average cluster } \\
\text { weight }\left(\mathrm{g} \text { cluster }{ }^{-1}\right) \\
( \pm \mathrm{SE})\end{array}$ & 2017 & 235.17 (17.37) & $216.80(17.37)$ & $226.27(17.72)$ & $278.07(28.33)$ & $258.70(17.37)$ \\
\hline $\begin{array}{c}\text { Average cluster } \\
\text { weight }\left(\mathrm{g} \text { cluster }{ }^{-1}\right) \\
( \pm \mathrm{SE})\end{array}$ & 2018 & $239.02(25.15)$ & $215.32(24.13)$ & $217.47(24.13)$ & 273.51 (25.39) & 221.21 (24.13) \\
\hline $\begin{array}{c}\text { Average berry } \\
\text { weight }\left(\mathrm{g} \text { berry }{ }^{-1}\right) \\
( \pm \mathrm{SE})\end{array}$ & 2016 & $1.55(0.09)$ & $1.58(0.09)$ & $1.71(0.09)$ & $1.68(0.09)$ & $1.60(0.09)$ \\
\hline $\begin{array}{c}\text { Average berry } \\
\text { weight }\left(\mathrm{g} \text { berry }{ }^{-1}\right) \\
( \pm \mathrm{SE})\end{array}$ & 2017 & $1.68(0.15)$ & $1.92(0.15)$ & $1.66(0.15)$ & $1.82(0.15)$ & $1.63(0.15)$ \\
\hline $\begin{array}{c}\text { Average berry } \\
\text { weight ( }\left(\mathrm{g} \text { berry }{ }^{-1}\right) \\
( \pm \mathrm{SE})\end{array}$ & 2018 & $2.18(0.13)$ & $2.36(0.13)$ & $2.35(0.13)$ & $2.26(0.13)$ & $2.22(0.13)$ \\
\hline
\end{tabular}

Flaming A = plants flamed only on 21 April in 2016 and 2017, 2 May in 2018. The most developed suckers were at the 12-13 BBCH growth stage. FlamingB = plants flamed only on 5 May in 2016 and 2017; 16 May in 2018. The most developed suckers were at the $15-16 \mathrm{BBCH}$ growth stage. Flaming $\mathrm{C}=$ plants flamed on 21 April and 5 May in 2016 and 2017; 2 May and 16 May 2018. Hand = plants hand suckered on 21 April 2016 and 2017; 2 May in 2018. Control $=$ no suckered plants.

Least-squares means and standard errors of the total soluble solids, $\mathrm{pH}$ and tartaric acid as affected by the type of treatment and the year are reported in Table 6 . The values of total soluble solids, $\mathrm{pH}$ and tartaric acid were statistically similar between treatments in all the years. In 2016, the total soluble solids and $\mathrm{pH}$ values were significantly lower compared to values estimated in 2017 and 2018 for all the treatments. The amount of tartaric acid was significantly higher in 2016 compared to 2017 and 2018 for all the treatments. The total soluble solids, $\mathrm{pH}$ and tartaric acid content were similar in 2017 and 2018 for all the treatments. As total soluble solids increase in the berries, the juice $\mathrm{pH}$ rises and the tartaric acid declines. 
Table 6. Least-squares means and standard errors of the total soluble solids, $\mathrm{pH}$, and tartaric acid as affected by the type of treatment and the year.

\begin{tabular}{ccccccc}
\hline Variable & Year & \multicolumn{5}{c}{ Treatment } \\
\cline { 3 - 7 } & FlamingA & FlamingB & FlamingC & Hand & Control \\
\hline $\begin{array}{c}\text { Total soluble } \\
\text { solids }\left({ }^{\circ} \text { Brix }\right) \\
( \pm \text { SE })\end{array}$ & 2016 & $20.26(0.59)$ & $20.38(0.59)$ & $20.74(0.59)$ & $20.74(0.59)$ & $20.70(0.54)$ \\
$\begin{array}{c}\text { Total soluble } \\
\text { solids }\left({ }^{\circ} \text { Brix }\right) \\
( \pm \text { SE })\end{array}$ & 2017 & $22.75(0.86)$ & $22.90(0.86)$ & $23.70(0.86)$ & $23.60(0.86)$ & $22.70(0.86)$ \\
$\begin{array}{c}\text { Total soluble } \\
\text { solids }\left({ }^{\circ} \text { Brix }\right) \\
( \pm \text { SE })\end{array}$ & 2018 & $21.80(0.65)$ & $22.13(0.65)$ & $22.25(0.65)$ & $22.38(0.65)$ & $22.43(0.65)$ \\
$\begin{array}{c}\text { pH }( \pm \text { SE) } \\
\text { pH }( \pm \text { SE) } \\
\text { pH }( \pm \text { SE) }\end{array}$ & 2016 & $3.13(0.03)$ & $3.11(0.03)$ & $3.12(0.03)$ & $3.18(0.03)$ & $3.12(0.03)$ \\
$\begin{array}{c}\text { Tartaric acid } \\
\left(\mathrm{g} \mathrm{L}^{-1}\right)\end{array}$ & 2018 & $3.41(0.06)$ & $3.48(0.06)$ & $3.43(0.06)$ & $3.47(0.06)$ & $3.47(0.06)$ \\
$\begin{array}{c}\text { Tartaric acid } \\
\left(\mathrm{g} \mathrm{L}{ }^{-1}\right)\end{array}$ & 2017 & $6.59(0.05)$ & $3.46(0.05)$ & $3.54(0.05)$ & $3.44(0.05)$ & $3.54(0.05)$ \\
$\begin{array}{c}\text { Tartaric acid } \\
\left(\mathrm{g} \mathrm{L}{ }^{-1}\right)\end{array}$ & 2018 & $6.50(0.20)$ & $6.36(0.20)$ & $6.15(0.20)$ & $6.40(0.18)$ \\
\hline
\end{tabular}

Flaming A = plants flamed only on 21 April in 2016 and 2017, 2 May in 2018. The most developed suckers were at the 12-13 BBCH growth stage. FlamingB = plants flamed only on 5 May in 2016 and 2017; 16 May in 2018. The most developed suckers were at the 15-16 BBCH growth stage. Flaming $\mathrm{C}=$ plants flamed on 21 April and 5 May in 2016 and 2017; 2 May and 16 May 2018. Hand = plants hand suckered on 21 April 2016 and 2017; 2 May in 2018. Control $=$ no suckered plants.

\subsection{Flaming Machine Performance and Costs}

Flaming machine performance and costs are reported in Table 7. It should be pointed out that a large amount of the variable costs for conducting flaming was due to the high cost of the LPG in Italy $\left(2.25 € \mathrm{~kg}^{-1}\right)$, and that flaming may be less expensive in countries where the LPG (or propane) would costs less (e.g., in the USA the propane cost is equivalent to $0.48 € \mathrm{~kg}^{-1}$ ).

Table 7. Flaming machine performance and costs estimation. The machine was used coupled with a SAME Frutteto 100 tractor.

\begin{tabular}{|c|c|}
\hline \multicolumn{2}{|l|}{ Performance } \\
\hline Forward speed $\left(\mathrm{km} \mathrm{h}^{-1}\right)$ & 3.00 \\
\hline Working width $(\mathrm{m})$ & 1.05 \\
\hline Theoretical field capacity $\left(\right.$ ha $\mathrm{h}^{-1}$ ) & 0.31 \\
\hline Theoretical field time $(\mathrm{h}) *$ & 3.17 \\
\hline Turning time $(\mathrm{h}) *$ & 0.23 \\
\hline Time to refuel the tractor and/or replace empty LPG tanks (h) * & 0.19 \\
\hline Machine adjustment time (includes plugging and unplugging) (h) & 0.25 \\
\hline Total time $(\mathrm{h}) *$ & 3.84 \\
\hline Field efficiency * & 0.83 \\
\hline Effective field capacity $\left(\right.$ ha $\left.\mathrm{h}^{-1}\right) *$ & 0.26 \\
\hline \multicolumn{2}{|l|}{ Costs } \\
\hline Tractor cost per hour $\left(€ \mathrm{~h}^{-1}\right)$ * & 28.15 \\
\hline Tractor cost per use $\left(€ \mathrm{ha}^{-1}\right) *$ & 108.10 \\
\hline Flaming machine cost per hour $\left(€ \mathrm{~h}^{-1}\right)^{*}$ & 43.23 \\
\hline Flaming machine cost per use $\left(€ \mathrm{ha}^{-1}\right)^{*}$ & 137.23 \\
\hline Total cost per hour $\left(€ \mathrm{~h}^{-1}\right)^{*}$ & 71.38 \\
\hline Total cost per use $(€ \text { ha })^{*}$ & 245.33 \\
\hline
\end{tabular}




\section{Discussion}

Flame suckering reduced the number of suckers observed before the start of the experiment each year (Table 2). The date of flaming influenced the final number of suckers. In fact, in 2017 and 2018, the suckers removed with flaming on 21 April 2017 and 2 May 2018 led to a significant resprouting of suckers compared to the flaming two weeks later on 5 May 2017 and 16 May 2018 (or applied on both dates), which resulted in a nonsignificant reduction in the initial number of suckers (Table 2). Flame suckering was more effective if not carried out too early, because although the suckers were more developed (15-16 BBCH growth stage vs 12-13 BBCH growth stage), and therefore would seem more difficult to devitalize, sucker resprouting is more difficult due to the more developed main grape productive shoots (18-19 $\mathrm{BBCH}$ growth stage vs 15-16 $\mathrm{BBCH}$ growth stage).

In fact, a vine is a 'acrotonic branching' plant due to the distal position of shoots, irrespectively of its size relative to the parent stem [26]. More developed shoots exploit their higher sink strength, and absorb more nutrients [27,28]. Apical dominance of Vitis vinifera L. increases with increasing temperature [29]. This explains why, over time, there was a significant decrease in the resprouting of basal buds. The amount of resprouting, in the first two weeks after the start of the experiment, was the same as the resprouting in the hand-suckered plots, where suckers were completely removed during the operation. However, two weeks later the number of suckers was no longer zero, but on average there were two suckers per plant in 2016 and one sucker per plant in 2017 and 2018. This amount, added to approximately one sucker per plant which flaming did not devitalize, led to the nonsignificant decrease in the number of suckers compared to the initial number when FlamingA was applied in 2017 and 2018. There was no resprouting in the control plants because new buds only sprout when buds (e.g., the suckers) have been removed from the plant [4].

In the three-year experiment, the yield components and grape composition were similar among treatments, suggesting that flaming did not damage the grapevine plants, or modify the quality of the grapes. Byrne and Howell [3] found that sucker removal increased the yield per vine. In our experiment, the low plant potential fertility due to the low number of buds per vine, the tendency to an excess of total leaf surface per plant in relation to the quantity of grape production, and the few suckers per plant (a maximum of around four suckers per control plant in 2016), although statistically higher compared to the flame- and hand-suckering, was probably not enough to negatively affect the production of grapes.

Although the number of suckers per plant did not influence the yield, and suckers were manually removed during the winter pruning (as per general vineyard procedure), suckering during the spring is nevertheless required. This is because the presence of suckers during the vine growing season can cause problems during vineyard management such as weed, insect, and disease control, and mechanical harvest [3]. Moreover, postponing the suckering of a high number of suckers until winter pruning would significantly increase the cost of manually removing the excessively developed and lignified shoots, and most of all, would increase the development of basal buds capable of resprouting [4]. Finally, the majority of vine disease pathogens infect via winter wounds, because winter is associated with high rainfall, which increases inoculum availability, increasing the risk of sucker wounds acting as portals for grapevine trunk pathogen infections [30,31].

The reduction in yield from 2016 to 2018 cannot be attributed to the suckering, because the reduction was found in all treatments indiscriminately. It was probably the result of the dry year in 2017 (Figure 1), which led to a lower potential fertility for 2018, resulting in a lower number of clusters. The higher average berry weight estimated in 2018 was probably because of the lower number of clusters and the higher rainfall occurring during the 2018 growing season compared to 2016 and 2017 (Figure 1). Concerning grape composition, as the total soluble solids increase in the berries, the juice $\mathrm{pH}$ rises and the tartaric acid declines. 


\section{Conclusions}

Almost always, flame-suckering led to a significant reduction in suckers in each year of application, even if suckers flamed one time at the $12-13 \mathrm{BBCH}$ growth stage (FlamingA) did not show a reduction in the initial number of suckers in 2017 and 2018 (Table 2). On the other hand, flaming when suckers were at the 15-16 BBCH growth stage (when vine main shoots were at the 18-19 BBCH) (FlamingB and FlamingC) were the most effective flaming treatments, thus suggesting that delaying flame suckering reduces the number of suckers that resprout. Double-flaming (FlamingC) significantly reduced the number of suckers compared to hand-suckering alone in 2016, suggesting that the time when suckers are removed is probably more important than the number of flaming treatments. Moreover, conducting flame-suckering only once reduces by half the total cost per use. Flame suckering thus seems to be a valid alternative to the use of chemicals for organic growers. In addition, the number of suckers removed by flaming was similar to that of manual suckering. This is an important outcome, because hand suckering is very expensive (e.g., about $10 € \mathrm{~h}^{-1}$ for a labour time up to $60-70 \mathrm{~h} \mathrm{ha}^{-1}$ ). Future studies could investigate the simultaneous use of flaming for both suckering and weed control, in order to provide an economic, sustainable alternative to a chemical approach for organic grapevine growers.

Supplementary Materials: The following are available online at http:/ /www.mdpi.com/2073-4395/9/3/147/s1, Video S1: Flame suckering applied on 21 April 2016 at the 12-13 BBCH sucker growth stage.

Author Contributions: Conceptualization, M.R., L.M., C.F., M.F., A.P. and C.D.; methodology, M.R., L.M., C.F., M.F., A.P. and C.D.; validation, L.M., M.R., C.F., M.F., A.P., and C.D.; formal analysis, L.M., M.R., C.F., M.F., A.P. and C.D.; investigation, L.M., M.R., C.F., M.F., A.P. and C.D.; resources, L.M., M.R., C.F., M.F., A.P. and C.D.; data curation, L.M.; writing—original draft preparation, L.M.; writing—review and editing, L.M., M.R., C.F., M.F., A.P. and C.D.; visualization, L.M., M.R., C.F., M.F., A.P. and C.D.; supervision, L.M., M.R., C.F., M.F., A.P. and C.D.; project administration, M.R., L.M., C.F., and C.D.

Funding: This research received no external funding.

Acknowledgments: This study was self-financed by the Department of Agriculture, Food and Environment of the University of Pisa (Pisa, Italy). The authors would like to thank Adrian Wallwork (e4ac.com) for providing the English language editing of this paper; Valentina Panicucci from the Department of Agriculture, Food and Environment of University of Pisa (Pisa, Italy) for her contribution to the 2016 experiment; Piergiorgio Castellani from Castellani Spa (Pontedera, Pisa, Italy) for hosting the trials; and Alessandro Moretto from Castellani Spa, Paolo Belluomini and Piero Puntoni from the Department of Agriculture, Food and Environment of University of Pisa for their technical support.

Conflicts of Interest: The authors declare no conflicts of interest.

\section{References}

1. Hellman, E.W. Grapevine structure and function. In Oregon Viticulture; Hellman, E.W., Ed.; Oregon State University Press: Corvallis, OR, USA, 2003; pp. 5-19.

2. Dolci, M.; Galeotti, F.; Curir, P.; Schellino, L.; Gay, G. New 2-naphthyloxyacetates for trunk sucker growth control on grapevine (Vitis vinifera L.). Plant Growth Regul. 2004, 44, 47-52. [CrossRef]

3. Byrne, M.E.; Howell, G.S. Initial response of Baco noir grapevines to pruning severity, sucker removal, and weed control. Am. J. Enol. Vitic. 1978, 29, 192-198.

4. Fregoni, M. Chapter X. La potatura della vite. In Viticoltura di Qualità; Edizioni l'Informatore Agrario: Verona, Italy, 1999; pp. 377-492. (In Italian)

5. Kang, F.; Wang, H.; Pierce, F.J.; Zhang, Q.; Wang, S. Sucker detection of grapevines for targeted spray using optical Sensors. Trans. ASABE 2012, 55, 2007-2014. [CrossRef]

6. Paliotti, A.; Poni, S.; Silvestroni, O. Interventi in verde. Spollonatura. In La nuova Viticoltura. Innovazioni Tecniche per Modelli Produttivi Efficienti e Sostenibili; Edagricole: Milano, Italy, 2015; p. 141.

7. Ahmedullah, M.; Wolfe, W.H. Control of sucker growth on Vitis vinifera L. cultivar Sauvignon Blanc with naphthalene acetic acid. Am. J. Enol. Vitic. 1982, 33, 198-200.

8. Mojžiš, M. Energetic requirements of flame weed control. Res. Agric. Eng. 2002, 48, 94-97.

9. Knezevic, S. Flame weeding in corn, soybean and sunflower. In Proceedings of the 8th International Conference on Information and Communication Technologies in Agriculture, Food and Environment (HAICTA 2017), Chania, Crete Island, Greece, 21-24 September 2017; pp. 390-394. 
10. Martelloni, L.; Fontanelli, M.; Frasconi, C.; Raffaelli, M.; Peruzzi, A. Cross-flaming application for intra-row weed control in maize. Appl. Eng. Agric. 2016, 32, 569-578. [CrossRef]

11. Martelloni, L.; Fontanelli, M.; Frasconi, C.; Raffaelli, M.; Pirchio, M.; Peruzzi, A. A combined flamer-cultivator for weed control during the harvesting season of asparagus green spears. Span. J. Agric. Res. 2017, 15, e0203. [CrossRef]

12. Neilson, B.D.; Bruening, C.A.; Stepanovic, S.; Datta, A.; Knezevic, S.; Gogos, G. Design and field testing of a combined flaming and cultivation implement for effective weed control. Appl. Eng. Agric. 2017, 33, 43-54.

13. Regione Toscana. Settore Idrologico Regionale. Ricerca dati. Centro Funzionale Regionale di Monitoraggio Meteo-Idrologico. Available online: http:/ / www.sir.toscana.it/ricerca-dati (accessed on 12 February 2019).

14. Officine Mingozzi. Technical Info. Available online: http://www.pirodiserbo.it/dati_tecnici_pfv.pdf (accessed on 12 February 2019).

15. Raffaelli, M.; Frasconi, C.; Fontanelli, M.; Martelloni, L.; Peruzzi, A. LPG burners for weed control. Appl. Eng. Agric. 2015, 31, 717-731. [CrossRef]

16. Frasconi, C.; Martelloni, L.; Fontanelli, M.; Raffaelli, M.; Marzialetti, P.; Peruzzi, A. Thermal weed control in Photinia $\times$ fraseri "Red Robin" container nurseries. Appl. Eng. Agric. 2017, 33, 345-356. [CrossRef]

17. Frasconi, C.; Martelloni, L.; Antichi, D.; Raffaelli, M.; Fontanelli, M.; Peruzzi, A.; Benincasa, P.; Tosti, G. Combining roller crimpers and flaming for the termination of cover crops in herbicide-free no-till cropping systems. PLoS ONE 2019, 14, e0211573. [CrossRef] [PubMed]

18. Martelloni, L.; Caturegli, L.; Frasconi, C.; Gaetani, M.; Grossi, N.; Magni, S.; Peruzzi, A.; Pirchio, M.; Raffaelli, M.; Volterrani, M.; et al. Use of flaming to control weeds in 'Patriot' hybrid bermudagrass. Horttechnology 2018, 28, 843-850. [CrossRef]

19. Peruzzi, A.; Martelloni, L.; Frasconi, C.; Fontanelli, M.; Pirchio, M.; Raffaelli, M. Machines for nonchemical intra-row weed control in narrow and wide-row crops: A review. J. Agric. Eng. 2017, 48, 57-70. [CrossRef]

20. Lorenz, D.H.; Eichhorn, K.W.; Bleiholder, H.; Klose, R.; Meier, U.; Weber, E. Growth stages of the grapevine: Phenological growth stages of the grapevine (Vitis vinifera L. ssp. vinifera)-Codes and descriptions according to the extended BBCH scale. Aust. J. Grape Wine Res. 1995, 1, 100-103. [CrossRef]

21. Hunt, D. Chapter 4. Costs. In Farm Power and Machinery Management; Waveland Press: Long Grave, IL, USA, 2001; pp. 75-77.

22. Kuznetsova, A.; Brockhoff, P.B.; Christensen, R.H.B. lmerTest: Tests in Linear Mixed Effects Models. R Package Version 2.0-32. Available online: https://CRAN.R-project.org/package=lmerTest (accessed on 12 February 2019).

23. R Core Team. R: A Language and Environment for Statistical Computing; R Foundation for Statistical Computing: Vienna, Austria. Available online: https:/ / www.R-project.org/ (accessed on 12 February 2019).

24. Lenth, R. Emmeans: Estimated Marginal Means, aka Least-Squares Means. R Package Version 1.2. 2018. Available online: https: / /CRAN.R-project.org/package=emmeans (accessed on 12 February 2019).

25. Knezevic, A. Overlapping Confidence Intervals and Statistical Significance. 2008. Available online: https: / / www.cscu.cornell.edu/news/statnews/stnews73.pdf (accessed on 12 February 2019).

26. Bell, A.D. Plant Form: An Illustrated Guide to Flowering Plant Morphology; Oxford University Press: New York, NY, USA, 1991.

27. Williams, L. Growth of 'Thompson Seedless' grapevines. I. Leaf area development and dry weight distribution. J. Am. Soc. Hortic. Sci. 1987, 112, 325-330.

28. Miller, D.P.; Howell, G.S.; Flore, J.A. Effect of shoot number on potted grapevines. Canopy development and morphology. Am. J. Enol. Vitic. 1996, 47, 244-250.

29. Buttrose, M.S. Some effects of light intensity and temperature on dry weight and shoot growth of grape-vine. Ann Bot. 1968, 32, 753-765. [CrossRef] 
30. Lecomte, P.; Bailey, D.J. Studies on the infestation by Eutypa lata of grapevine spring wounds. Vitis 2011, 50, $35-51$.

31. Makatini, G.H. The Role of Sucker Wounds as Portals for Grapevine Trunk Pathogen Infections. Master's Thesis, Plant Pathology, MScAgric, Stellenbosch University, Stellenbosch, South Africa. Available online: http:/ / hdl.handle.net/10019.1/86599 (accessed on 13 February 2019). 